\title{
Optimization of RAPD-PCR Conditions for the Study of Genetic Diversity in Nepalese Isolates of Bacillus thuringiensis Berliner
}

\author{
Jaishree Sijapati, Neesha Rana, Prabina Rana and Sangita Shrestha \\ Nepal Academy of Science and Technology (NAST) \\ Khumaltar, Lalitpur
}

\begin{abstract}
Random amplified polymorphic DNA (RAPD) is a simple and reliable method to detect DNA polymorphism and has been used extensively for genetic diversity studies. In the present investigation the RAPD reaction and cycling conditions were optimized for generating RAPD fingerprints of ten Nepalese strains of Bacillus thuringiensis Berliner (Bt) isolated from an altitudinal range of 70 meter above sea level (masl) to 5050 masl. To determine the optimum conditions, different concentrations of $\mathrm{MgCl}_{2}$, template DNA, Taq DNA polymerase, primer, dNTPs as well as different cycling programs were analyzed. Reproducible amplification patterns were obtained using $0.4 \mu \mathrm{M}$ of primer, $2.5 \mathrm{mM}$ of $\mathrm{MgCl}_{2}, 125 \mathrm{ng}$ of template DNA, $0.2 \mathrm{mM}$ of dNTPs and $1 \mathrm{U}$ Taq DNA polymerase in $25 \mu \mathrm{l}$ of the reaction volume. Cycling programs were also optimized. Out of 100 arbitrary primers screened, amplification performed with 24 primers generated the best RAPD fingerprints. The optimized RAPD-PCR conditions and the selected primers are suitable for further work on genetic diversity analysis of Nepalese isolates of $B t$.
\end{abstract}

Key words: DNA fingerprint, primer, Taq DNA polymerase, template DNA

\section{Introduction}

Bacillus thuringiensis Berliner (Bt) is a spore forming, crystalliferous Gram positive bacteria of the family Bacillaceae (Schnepf et al.1998). During sporulation, it produces intracellular insecticidal crystal protein (cry protein) that is toxic to insect larvae in the orders Lepidoptera, Diptera, Coleoptera etc. The cry protein from $B t$ has been developed as a successful biological agent to control insect pests.

Morphological and physiological characteristics have traditionally provided a wealth of Bacillus systematic information for establishing Bacillus classification system (Quingming et al.1997). The development of molecular techniques such as DNA-DNA hybridization and DNA sequencing in bacterial taxonomy have permitted objective determination of inter and intra relatedness of species. However, all these techniques are time consuming, expensive and complex while dealing with a large number of strains.

More recently, arbitrarily primed PCR-base techniques (variously named as RAPDs, AP-PCR and
DAF) have been introduced allowing rapid screening of a large number of genotypes for the study of genetic diversity and systematic relationships (Williams et al. 1990, Welsh \& McClelland 1990, Caetano-Annoles et al.1991a, b). These techniques use short (4-10 bp) synthetic deoxyribonucleotides of arbitrary sequences as primers and do not require specific sequence information for the design of PCR primers. Because the number of potential primers that can be used is very large, numerous polymorphisms can be detected even between closely related organisms.

Of these, RAPD has been a very popular employed technique to generate genus-specific, species specific, or strain-specific diagnostics DNA fragments or fingerprints, identifying genes linked to traits of interest; undertaking genetic diversity studies and gene mapping for development of diagnostics, etc. (Abad et al. 1998, Ransom et al. 1998, Bazzicalup \& Fani 1996).

Nepal is rich in biological diversity due to its unique topography, geography and climatic gradients. 
Ten local isolates of $B$. thuringiensis were isolated from different geographical regions of Nepal varying in altitudes ranging from75 masl-5050 masl. (Rana et al. 2002 a,b). Present investigation has been undertaken to optimize RAPD-PCR reaction and cycling conditions for the generation of RAPD profiles for the study of genetic diversity and relationship in Nepalese isolates of $B$. thuringiensis species.

\section{Materials and Methods}

Ten local strains (Table 1) isolated from various geographical location of Nepal and one commercial strain has been used in the present study.

Table 1. B. thuringiensis strains used for optimization

\begin{tabular}{llll}
\hline S.N & Area & Code No. & Altitude (masl) \\
\hline 1 & Nepalgunj & Nep1 & 144 \\
2 & Nepalgunj & Nep2 & 144 \\
3 & Pokhara & Bag1C & 827 \\
4 & Pokhara & Bag2A & 827 \\
5 & Chitwan & Chit-5 & 400 \\
6 & Biratnagar & Birat-6 & 72 \\
7 & Biratnagar & Bir2 & 72 \\
8 & Lobuche & Lob6 & 5000 \\
9 & Lobuche & Lob9 & 5050 \\
10 & Lobuche & Lob10 & 5050 \\
11 & Btk (ringer) & Btk & - \\
\hline
\end{tabular}

\section{DNA extraction}

Four different DNA extraction techniques (Bravo et al. 1998, Juarez-Perez et al. 1997, Ceron et.al. 1995 and Hansen et.al. 2001) were assessed for generating DNA fingerprinting.

\section{DNA estimation}

DNA quantification as well as quality assessment was carried out spectrophotometrically using Biophotometer (Eppendorf - AG 22331, Germany).

\section{Gel electrophoresis}

The quality of extracted DNA was assessed using 1.5 $\%$ agarose gel electrophoresis ( in EMBI TEC Santiago, CA gel tank) in TAE buffer (Tris / Acetic Acid / EDTA) at $25 \mathrm{~V}(4.2 \mathrm{~V} / \mathrm{cm})$ for half an hour. PCR products were electrophoresed on $1.5 \%(\mathrm{w} / \mathrm{v})$ agarose gel in $1 \mathrm{x}$ TAE buffer at $25 \mathrm{~V}(4.2 \mathrm{~V} / \mathrm{cm})$ for $1.5 \mathrm{~h}$. The gels were stained with ethidium bromide $(10 \mathrm{mg} / \mathrm{ml}$ solution) for 45 minutes, de-stained for 15 minutes in water prior to visualization and photography using UV transilluminator (UVITEC, Japan) and Polaroid Gelcam (UK).

\section{PCR optimization}

Best RAPD-PCR cycling conditions for $B t$ was selected from four randomly selected PCR cycles viz., Yu and Pauls (1994), Giovana et al .(2001), Arango et al.
(2002), Araujo et al. (2004) and were used for DNA fingerprinting.

PCR reactions were performed in $25 \mu$ l reaction volume. The optimum RAPD-PCR reaction conditions were selected by varying several parameters viz. DNA concentration $(50,75,100,125,150,175,200,225$, 250 and $275 \mathrm{ng}) ; \mathrm{MgCl}_{2}$ concentration $(1.5,2.5,3.5$ and 4.5.mM); Primer concentration (0.1, 0.2, 0.3, 0.4, 0.5 and $0.6 \mu \mathrm{M})$ Taq DNA polymerase concentration $(0.5,1.0,1.5$ and $2.0 \mathrm{U})$ and dNTP concentration (100, 200, 300 and $400 \mathrm{mM}$ ).

\section{Primer screening}

Using optimized reaction and cycling conditions for $B t$, 100 UBC (University of British Columbia,Vancouver, Canada) random primers were screened and best primers producing multiple crispy bands were selected for subsequent profiling experiments.

\section{Results and Discussion}

Selection of DNA extraction protocol for $B t$

Among the four protocols considered for the DNA extraction technique for $B t$, modified method of Hansen et al. (2001) proved to be efficacious in yielding strong and reliable amplification products as compared to 
other methods. The quality of the template DNA has a great effect on the generation and resolution of amplified products. Because the amplification process requires such small amounts of template DNA, extraction procedures that emphasize purity rather than quantity are usually most appropriate for RAPD research (Weeden et al. 1992).

\section{Optimization of RAPD -PCR reaction and cycling parameters}

For the generation of DNA fingerprints for RAPDbased genetic diversity studies, a number of parameters starting from DNA isolation procedure, template DNA concentration, $\mathrm{MgCl}_{2}$ concentration, Taq DNA polymerase concentration, primer concentration and dNTPs concentration need to be optimized as it is highly sensitive to reaction and cycling parameters resulting into lack of reproducibility (Weeden et.al. 1992). Furthermore, change of thermal cycle could also induce non-reproducibility. Therefore, this technique demands strict maintenance of all the parameters following its final optimization. Optimized RAPD-PCR reaction and cycling parameters are shown in Table 2.

Table 2. Optimization of the RAPD-PCR reaction parameters for Nepalese Bacillus thuringiensis isolates

\begin{tabular}{|c|c|c|c|}
\hline S. N. & PCR parameters & $\begin{array}{c}\text { Tested range } \\
\text { (Concentration / RAPD cycles) }\end{array}$ & $\begin{array}{l}\text { Optimum } \\
\text { conditions }\end{array}$ \\
\hline 1. & DNA concentration (ng) & $50,75,100,125,150,175,200,225,250$ and 275 & $125 \mathrm{ng}$ \\
\hline 2. & $\mathrm{MgCl}_{2}$ concentration $(\mathrm{mM})$ & $1.5,2.5,3.5$ and 4.5 & $2.5 \mathrm{mM}$ \\
\hline 3. & dNTPs concentration $(\mathrm{mM})$ & $100,200,300$ and 400 & $0.2 \mathrm{mM}$ \\
\hline 4. & Primer concentration $(\mu \mathrm{M})$ & $0.1,0.2,0.3,0.4,0.5$ and 0.6 & $0.4 \mu \mathrm{M}$ \\
\hline \multirow[t]{2}{*}{5.} & Taq polymerase & & \\
\hline & concentration $(\mathrm{U})$ & $0.5,1.0,1.5,2.0$ and 2.5 & $1.0 \mathrm{U}$ \\
\hline \multirow[t]{6}{*}{6.} & PCR programs & $\begin{array}{l}\text { a) } 4 \text { min of initial denaturation at } 95^{\circ} \mathrm{C}, 45 \text { cycles } \\
\text { of denaturation at } 94^{\circ} \mathrm{C} \text { for } 1 \mathrm{~min} \text {, annealing at } \\
36^{\circ} \mathrm{C} \text { for } 1 \text { min and extension at } 72^{\circ} \mathrm{C} \text {. (Giovana } \\
\text { et al. 2001) }\end{array}$ & a) Giovana el al 2001 \\
\hline & & $\begin{array}{l}\text { b) } 3 \mathrm{~min} \text { of initial denaturation at } 95^{\circ} \mathrm{C}, 40 \text { cycles } \\
\text { of denaturation at } 95^{\circ} \mathrm{C} \text { for } 1 \mathrm{~min} \text {, annealing at } \\
34^{\circ} \mathrm{C} \text { for } 2 \mathrm{~min} \text { and extension at } 72^{\circ} \mathrm{C} \text {. Final } \\
\text { extension at } 72^{\circ} \mathrm{C} \text { for } 5 \mathrm{~min} \text {. (Arango et. al. } 2002 \text { ). }\end{array}$ & \\
\hline & & $\begin{array}{l}\text { c) } 4 \text { min of initial denaturation at } 92^{\circ} \mathrm{C}, 40 \text { cycles of } \\
\text { denaturation at } 92^{\circ} \mathrm{C} \text { for } 1 \mathrm{~min} \text {, annealing at } 37^{\circ} \mathrm{C} \\
\text { for } 2 \text { min and extension at } 72^{\circ} \mathrm{C} \text { for } 3 \text { mins. Final } \\
\text { extension at } 72^{\circ} \mathrm{C} \text { for } 3 \text { min.(Araujo et. al. } 2004 \text { ) }\end{array}$ & \\
\hline & & (d) 1 min of initial denaturation at $94^{\circ} \mathrm{C}, 35$ cycles & \\
\hline & & of denaturation at $94^{\circ} \mathrm{C}$ for $10 \mathrm{~s}$, annealing at $38^{\circ} \mathrm{C}$ & \\
\hline & & $\begin{array}{l}\text { for } 30 \mathrm{~s} \text { and extension at } 72^{\circ} \mathrm{C} \text { for } 60 \mathrm{~s} \text {. Final } \\
\left.\text { extension at } 72^{\circ} \mathrm{C} \text { for } 5 \mathrm{~min} \text { ( } \mathrm{Yu} \& \text { Pauls } 1994\right)\end{array}$ & \\
\hline
\end{tabular}


The ratio of DNA template to primer is one of the most critical factors to consider when optimizing the PCR. Therefore, a range of DNA concentrations should be tried against a fixed primer concentration for each DNA extraction protocol to obtain the ideal conditions (Tyler et al.1997). It was observed that the use of 125 ng of DNA in the PCR mix provided the best results (Fig. 1). The concentration of Taq DNA polymerase had an influence on the amplification. 1U of Taq DNA polymerase produced the best result.

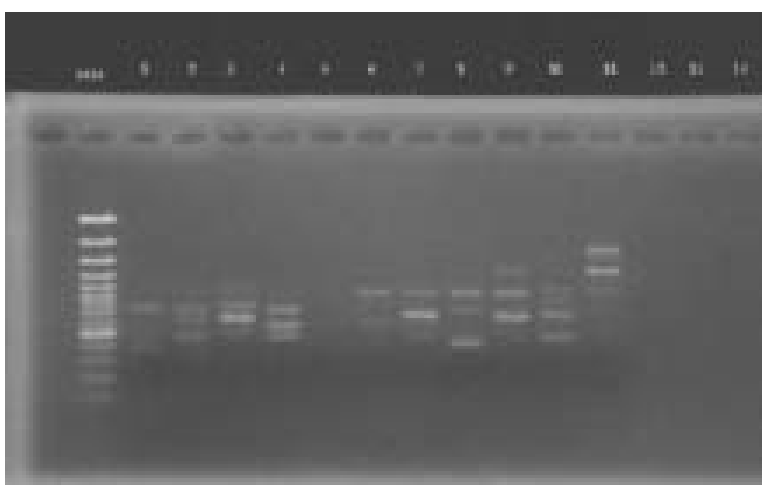

Fig. 1. RAPD-PCR assays for the selection of DNA concentration using primer UBC 1 and DNA of strain Lob 9. Lane marked MM are 100 base pair molecular weight marker; Lanes 1-4 and 6-11 having 50, 75, 100,125, 150, 175, 200, 225, 250 and 275ng of $\mathrm{Bt}$ DNA respectively.

The variation in $\mathrm{MgCl}_{2}$ concentration modified the RAPD profile. The best banding patterns were observed at $2.5 \mathrm{mM}$ concentration of $\mathrm{MgCl}_{2}$ (Fig 2). Lower concentration and higher concentrations of $\mathrm{MgCl}_{2}$ had significant effects upon the RAPD profile produced, revealing fewer and non-specific bands. Since the $\mathrm{MgCl}_{2}$ is co-factor of the Taq DNA polymerase enzyme, it influences the DNA amplification process. Lower quantities than the necessary ones lead to the amplification failure or deficient amplification whilst excess $\mathrm{Mg}^{2+}$ results in non-specific amplifications as a result of reduced enzyme fidelity (Saiki 1989).

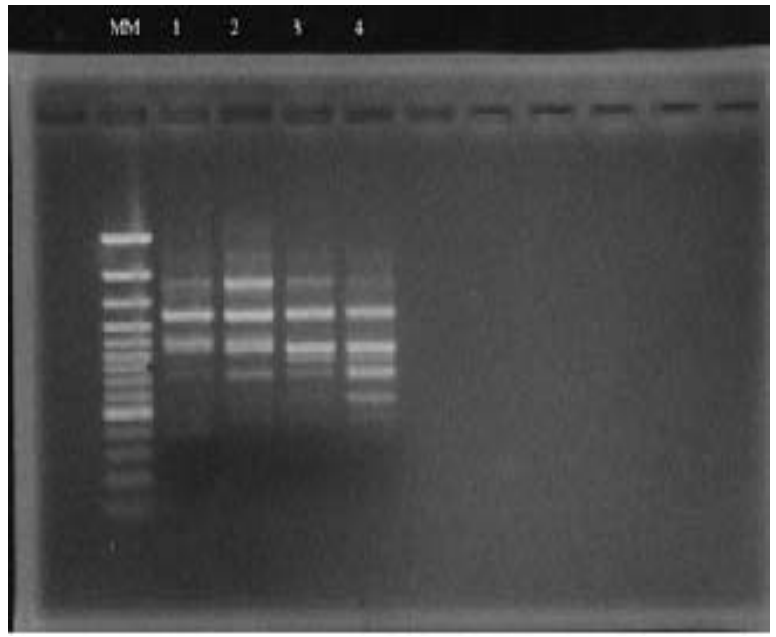

Fig. 2. RAPD - PCR of $\mathrm{Bt}$ for selection of $\mathrm{MgCl}_{2}$ concentration using primer UBC1 and DNA of Lob 9 strain. Lane marked MM is 100 base pair molecular weight marker. Lanes 1-4 RAPD fingerprint in of varying concentration of $\mathrm{MgCl}_{2} 1.5,2.5,3.5,4.5 \mathrm{mM}$ respectively.

After optimization of all the reagents, RAPD amplification was performed in a total volume of $25 \mathrm{ul}$ reaction mixture. Optimized RAPD-PCR reaction volume of $25 \mu \mathrm{l}$ contained $125 \mathrm{ng}$ of template DNA, $2.5 \mathrm{mM}$ of $\mathrm{MgCl}_{2}, 0.2 \mathrm{mM}$ each of dATP, dTTP, dGTP and dCTP, $2.5 \mu$ PCR buffer, $0.4 \mu \mathrm{M}$ primer and $1.0 \mathrm{U}$ of Taq DNA polymerase. The method of Giovana et al. (2001) produced the best result (Table 2).

\section{Primer Screening}

A series of 100 decamer primers from codes 1-100 (obtained from UBC) were tested. Amplification performed with 24 primers generated the best RAPD profiles and were found to amplify genomic DNA fragments with reproducible polymorphisms (Fig. $3 \&$ $4)$. The GC content of these primers ranged from 60$80 \%$. Amplified fragments ranged from $500 \mathrm{bp}$ to 1300 bp (Table 3). 
J. Sijapati et. al./Optimization of RAPD-PCR Conditions.

Table 3. Selected 10 bp random primers for Nepalese $B t$ isolates

\begin{tabular}{llll}
\hline S.N & Primer code & Nucleotide sequence 5 $^{\prime}$ to $3^{\prime}$ & GC $\%$ \\
\hline 1 & UBC 1 & CCTGGGCTTC & 70 \\
2 & UBC 2 & CCTGGGCTTG & 70 \\
3 & UBC 3 & CCTGGGCTTA & 60 \\
4 & UBC 4 & CCTGGGCTGG & 80 \\
5 & UBC 6 & CCTGGGCTA & 70 \\
6 & UBC 16 & GGTGGCGGGA & 80 \\
7 & UBC 17 & CCTGGGCCTC & 80 \\
8 & UBC 43 & AAAACCGGGC & 60 \\
9 & UBC 51 & CTACCCGTGC & 70 \\
10 & UBC 54 & GTCCCAGAGC & 70 \\
11 & UBC 55 & TCCCTCGTGC & 70 \\
12 & UBC 65 & AGGGGCGGGA & 80 \\
13 & UBC 66 & GAGGGCGTGA & 70 \\
14 & UBC 67 & GAGGGCGAGC & 80 \\
15 & UBC 71 & GAGGGCGAGG & 80 \\
16 & UBC 73 & GGGCACGCGA & 80 \\
17 & UBC 74 & GAGCACCTGA & 60 \\
18 & UBC 76 & GAGCACCAGT & 60 \\
19 & UBC 85 & GTGCTCGTGC & 70 \\
20 & UBC 86 & GGGGGGAAGG & 80 \\
21 & UBC 88 & CGGGGGATGG & 80 \\
22 & UBC 92 & CCTGGGCTTT & 60 \\
23 & UBC 96 & GGCGGCATGG & 80 \\
24 & UBC 97 & ATCTGCGAGC & 60 \\
\hline
\end{tabular}

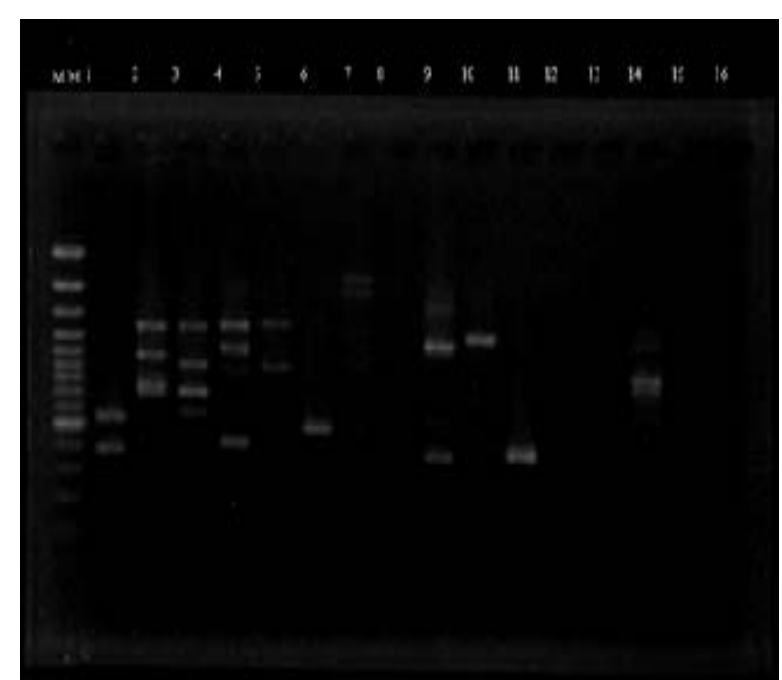

Fig. 3. RAPD - PCR for the primer screening experiment using DNA of Lob 9 strain. Lanes marked MM are 100 base pair molecular weight marker. Lanes 1-14, results of primer screening involving UBC primer $15-28$

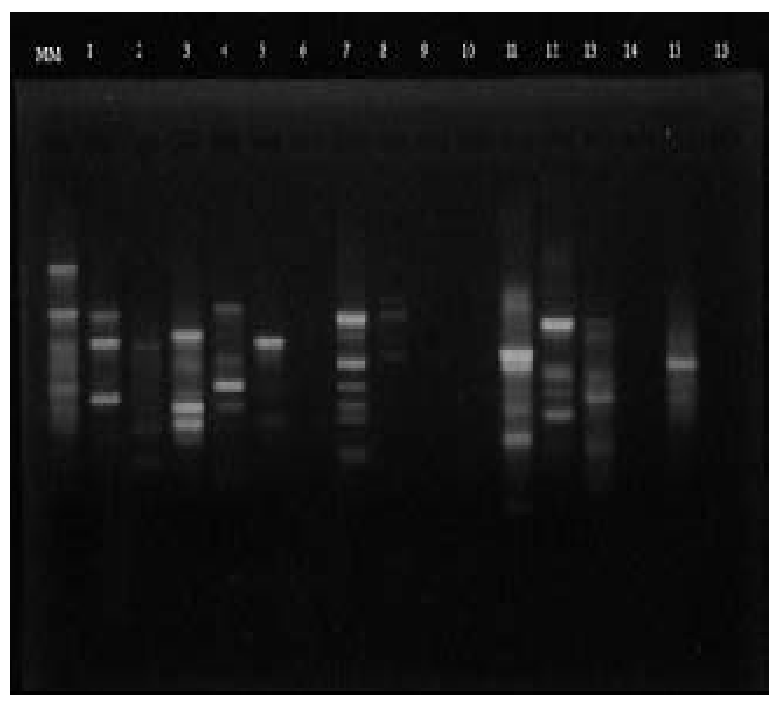

Fig. 4. RAPD - PCR of Bt for the primer screening using DNA of Lob 9 strain ane 1-16 results of primer screening involving UBC primer $85-100$ 
Almost all the tested parameters for RAPD-PCR like the concentration of template DNA, primer, $\mathrm{MgCl}_{2}$, Taq polymerase, dNTPs, temperature and PCR program were optimized which produced clear, multiple scorable amplified products suitable for RAPD amplification. The optimized reaction and cycling parameters thus obtained from present investigation will be used in subsequent experiment on RAPD profiling for genetic diversity study of Nepalese $B t$. isolates.

\section{Acknowledgement}

Our sincere thanks go to Prof. Dr. H. N. Bhattarai, Vice Chancellor and Prof. Dr. D. Subba, Secretary of NAST for their kind support. Our gratitude goes to Dr. Chiranjivi Regmi Chief, Technology Faculty of NAST for his kind encouragement and support in executing this research.

\section{References}

Abad, P., B. Pascual, J.V. Maroto, G.S. Lopez, M.J. Vicente and J. Alagarda. 1998. RAPD analysis of cultivated and wild yellow nutsedge (Cyperus esculentus L.). Weed Science 46:318-321.

Arango, J.A., M. Romero and S. Orduz. 2002. Diversity of Bacillus thuringiensis strains from Colombia with insecticidal activity against Spodooptera frugiperda (Lepidoptera: Noctuidae). Journal of Applied Microbiology 92:466-474.

Araujo,W. L, D. A. De. Angellis, J. L. Azevedo. 2004. Direct RAPD evaluation of bacteria without conventional DNA extraction.Braz. Arch. Boil .Technol. 47(3): 375-380.

Bazzicalupo, M., and R. Fani. 1996. The use of RAPD for generating specific DNA probes for microorganisms in methods in molecular biology .In: Species diagnostics protocols PCR and other nucleic acid methods (Eds J. P. Clapp). Humana Press Totowa, New Jersey. pp. 1-411.

Bravo, A., S. Sarabia, L. Lopez, H. Ontiveros, C. Abarca, A. Ortiz, M. Ortiz, L. Lina, F.J.Villalobos, G. Pena, M. Nunez-Valdez, M. Soberon and R.Quintero.1998.

Characterization of cry genes in a Mexican Bacillus thuringiensis strain collection. Applied and Environment Microbiology 64(12):4965-4972.

Caetano-Annoles, G., B.J. Bassam and P.M. Gresshoff. 1991a. DNA amplification fingerprinting: A strategy for genome analysis. Plant Molecular Biology Reporter 9:294-307.

Caetano-Annoles, G., B. J. Bassam and P.M. Gresshoff. 1991b. DNA amplification fingerprinting using very short arbitrary oligonucleotide primers. Biotechnology 9:553-556.
Ceron, J., L. Covarrubias, R. Quintero, A. Ortiz, M. Ortiz, E .Aranda, L. Lina and A. Bravo. 1994. PCR analysis of the cry I insecticidal crystal family genes from Bacillus thuringiensis. Applied and Environmental Microbiology 60:353-356.

Ceron, J., A. Ortiz, R .Quintero, L. Guereca and A. Bravo. 1995. Specific PCR primers directed to identify cry I and cry III genes within a Bacillus thuringiensis strain collection. Applied and Environmental Microbiology 61(11): $3826-3831$.

Giovana, V.A., B. Whittome, B. Shore and D. B. Levin. 2001. Identification of Bacillus thuringiensis subsp. kurstaki strain HD1-like bacteria from environmental and human samples after aerial spraying of Victoria, British Columbia, Canada, with Foray 48B. Applied and Environmental Microbiology 67 (3): 1035-1043.

Hansen, B. M. and N. B. Hendriksen. 2001. Detection of enderotoxic B. cerus and B.t strains by PCR analysis. Applied and Environmental Microbiology 67(1): 185-189.

Juarez-Perez, V. M., M. D. Ferrandis and R. Frutos. 1997. PCR-based approach for detection of novel Bacillus thuringiensis cry genes. Applied Environmental Microbiology 63(8):2997-3002.

Quingming, Y., X. Zongping and T. Tiansheng. 1997. Rapid classification of Bacillus isolates using RAPD technique. Wuhan University Journal of Natural Sciences 2(1):105-109.

Rana, P., J. Sijapati, N. Rana and C. Regmi. 2002 a. Distribution of Bacillus thuringiensis in the soils of Nepal and their bioassay. Nepal Journal of Science and Technology 4:27-31.

Rana, P., N. Rana, J. Sijapati, A. Giri and C. Regmi. 2002b. Prospects of Bacillus thuringiensis based biopesticides in Nepal. In: Proceeding of a National Seminar on Integrated Pest Management (September 25-26, 2002) Kathmandu (Eds. F. P. Neupane). Himal Resources Institute, Kathmandu. pp.63-68.

Ransom, C.V., D.S. Douches and J. J. Kells. 1998. Isozyme and RAPD variation among and within hemp dogbane (Apocynum cannabinus) population. Weed Science 46:408-413.

Saiki, R. 1989. The design and optimization of the PCR. In: PCR Technology: Principles and applications for DNA amplification (Eds..Erlich) A New York: MacMillan. p.716.

Schnepf, E., N. Crickmore, J. Van, R. D. Lereclus, J. Braum, J. Feitelson, D.R. Zeigler, D.H. Dean. 1998. Bacillus thuingiensis and its pesticidal crystal proteins. Microbiol. Mol. Biol. Rev. 62:775-806.

Tyler, K.D., G. Wang, S.D. Tyler and W.M. Johnson. 1997. Factors affecting reliability and reproducibility of amplification-based DNA fingerprinting of representative bacterial pathogens. Journal of Clinical Microbiology 35:339-346.

Weeden, N.F., G. M. Timmerman, M. Hemmat, B.E. Kneen and M.A. Lodhi. 1992. Inheritance and reliability of 


\section{J. Sijapati et. al./Optimization of RAPD-PCR Conditions.}

RAPD markers in application of RAPD technology to plant breeding. In: Joint Plant Breeding Symposia Series (November 1, 1992), Minneapolis, MN. Crop Science Society of America, Madison, WI. pp.12-17.

Welsh, J. and M. McClelland.1990. Fingerprinting genomes using PCR with arbitrary primers. Nucleic Acids Research. 18:166-176.

Williams, J.G.K., A. R. Kubelik, K. J. Livak, J. A. Rafalski and S. V. Tingey. 1990. DNA polymorphisms amplified by arbitrary primers are useful as genetic markers. Nucleic Acids Research 18: 6531-6535.

$\mathrm{Yu}$, K. and K.P. Pauls.1994. Optimization of DNA extraction and PCR procedures for random amplified polymorphic DNA (RAPD) analysis in plants. In: PCR Technology, Current Innovations (Eds. H.G. Griffin and A.M.Griffin ). CRC Press LLC, Boca Raton, Florida. pp.193-200. 
Nepal Journal of Science and Technology 9 (2008) 